\title{
The Epidemiology and Risk Factors for Renal Cancer
}

\author{
Tahir Qayyum ${ }^{\mathrm{a} b \mathrm{~b}} \quad$ Grenville Oades $^{\mathrm{c}} \quad$ Paul Horgan $^{\mathrm{b}} \quad$ Michael Aitchison $^{\mathrm{d}} \quad$ Joanne Edwards $^{\mathrm{a}}$ \\ annit of Experimental Therapeutics, Institute of Cancer, College of MVLS, University of Glasgow, Western Infirmary; \\ ${ }^{b}$ School of Medicine, College of MVLS, University of Glasgow, Royal Infirmary; 'Department of Urology, Southern General Hospital; \\ ${ }^{\mathrm{d}}$ Department of Urology, Gartnaval General Hospital, Glasgow, UK
}

\section{Key Words}

Epidemiology $\cdot$ Renal cancer $\cdot$ Risk factors

\begin{abstract}
Background: Renal cancer is a frequently occurring malignancy with over 270,000 new cases diagnosed and it being responsible for 110,000 deaths annually on a global basis. Incidence rates have gradually increased whilst mortality rates are starting to plateau. Objective: To review epidemiology and risk factors for renal cancer. Methods: The current data is based on a thorough review of available original and review articles on epidemiology and risk factors for renal cancer with a systemic literature search utilising Medline. Results: The prevalence of associated risk factors such as genetic susceptibility, smoking, hypertension and obesity are changing and could account for the changes in incidence whilst the role of diet and occupational exposure to carcinogens requires further investigation. Conclusion: Despite the evidence of various associated risk factors, further work is required from well designed studies to gain a greater understanding of the etiology of renal cancer.

Copyright $\odot 2012$ S. Karger AG, Basel
\end{abstract}

\section{Incidence and Survival Rates in Renal Cancer}

Worldwide, renal cancer is the 13th most common malignancy with over 270,000 new cases diagnosed in

\section{KARGER}

Fax +4161306 1234

E-Mail karger@karger.ch

www.karger.com
(C) 2012 S. Karger AG, Basel

1015-9770/12/0064-0169\$38.00/0

Accessible online at:

www.karger.com/cur
2008 [1]. In the UK alone, approximately 9,000 new cases of renal cancer are diagnosed each year [2]. Incidence rates have increased in the UK with age standardised incidence rates more than doubling between 1975 and 1977 and from 2007 to 2009 [2]. Age standardised ratios for both incidence and mortality is observed to be $50 \%$ lower in women compared to men [2]. Renal cell carcinoma (RCC) accounts for nearly $90 \%$ of all renal malignancies. There has been much debate that the increased incidence rate is due to the vast improvement in imaging modalities such as magnetic resonance imaging and computed tomography as well as the increased use of this imaging. It has been reported that there has been an increased rate of detection of incidental tumors which are asymptomatic and localised [3-6] but there has also been an increase detection of more advanced tumors and that the increase in incidence is real and cannot be solely accounted by incidentally detected tumors $[3,7]$.

Globally, renal cancer was responsible for over 110,000 deaths in 2008 [1]. Nearly 4,000 patients died from renal cancer in 2008 accounting for $2 \%$ of all cancer deaths in the UK [2]. And 20-30\% patients present with metastatic disease [8] with another $20 \%$ of patients undergoing nephrectomy developing metastases during subsequent follow-up [9]. This can account for the increasing mortality rates. Various factors are involved in survival after diagnosis such as tumor involvement as well as overall health but there is only a $50 \%$ chance of survival at 5 years following diagnosis [2]. 


\section{Risk Factors}

Approximately $75 \%$ of those diagnosed are over 60 years of age with the disease being rare in those under 50 [2] and reaching a plateau around 70-75 years of age [10]. Incidence rates have increased in all age groups but this increase is predominantly in those over 75 years of age [2]. In addition mortality rates have predominantly increased in those over 75 [2], confirming that renal cancer is predominantly a disease of the elderly.

Age standardised incidences suggest that men are at an increased risk of RCC [1] with it being the 6th most common cancer in men and the 9th most common in women in the UK [2]. The increase in overall incidence is replicated in the increase in incidences in both sexes with there being an obvious higher occurrence in males accounting for the overall increase suggesting that there is a higher predisposition of renal cancer in males than females. It has been reported that between 2007 and 2030 there will be a 27 and $18 \%$ increase in the incidence of renal cancer in males and females, respectively [11]. In 2009 the age standardised incidence risk per 100,000 was 15.5 in men compared to 8.2 in women in the UK [2].

Mortality rates are also higher in males than in females as maybe expected given the obvious difference in incidence rates in both sexes. In 2008 the age standardised mortality rate per 100,000 was 6 in men compared to 3.1 in women in the UK [2]. It has long been thought that incidence and mortality rates have been higher in males due to lifestyle factors such as cigarette smoking which has been historically higher in males and also exposure to industrial carcinogens due to differing occupational bias between the sexes.

Smoking is a well established risk factor for RCC with a meta-analysis reporting not only a difference in a smoker and a non-smoker but also a dose-dependant risk with the number of cigarettes smoked [12]. Compared to those whom never smoked, there was a $50 \%$ increase in the risk for males and a $20 \%$ increase risk for females [12]. This risk can be reduced after smoking cessation for more than 10 years $[10,12,13]$. It is thought that cigarette smoking increases the risk of RCC through chronic tissue hypoxia due carbon monoxide exposure [14] as well as evidence suggesting higher level of DNA damage in peripheral blood lymphocytes in those with RCC compared to controls [15].

It has been suggested that the different incidence rates observed between males and females maybe due to exposure to potential occupational carcinogens. The most extensively studied is the solvent trichloroethylene which is widely used as a metal degreaser and has been considered a human carcinogen by the International Agency for Research on Cancer as well as a common environmental contaminant [16]. A case controlled series in Europe reported an increased risk following exposure to trichloroethylene [17] with one review reporting increased risk of various malignancies including renal following exposure [18] and a meta-analysis suggesting a weak association with exposure to trichloroethylene [19] whilst others have reported that given the complexities of trichloroethylene pharmacokinetics and limitation of studies this prevents a definitive relationship [16, 18, 20]. Various other compounds have been investigated with one study reporting an association with lead which requires further investigation whilst associations have been reported for glass and wool fibres as well as brick dust [21, 22]. Exposure to industrial agents such as cadmium and, uranium has shown no relationship to RCC risk [10, 23, 24] and neither have arsenic, nitrate and radon in drinking water [10]. Interestingly an association between agricultural workers and RCC was reported [25] and an inverse relationship between exposure of ultraviolet light in men and RCC risk was observed [22].

Excess body weight has been established as a risk factor for RCC with it accounting for 30\% of cases in Europe [26]. Various prospective studies conducted worldwide have reported that overweight and obese individuals were found to have an elevated subsequent risk of RCC [27-30] with a meta-analysis of this work also suggesting that an association between body mass index and risk of RCC exists [31]. Some have suggested that body fat distribution is associated with an increased risk of RCC $[28,30]$ but evidence is limited suggesting that abdominal obesity is independent of body mass index with the association with RCC. Two factors closely related to each other and obesity is diet and physical activity. The majority of studies have demonstrated an inverse relationship between physical activity and RCC risk [32-40] with some authors reporting a dose response with further reduction of risk with increasing levels of activity [35, $37,38]$. Assessing dietary intake has reported mixed results with association with RCC. The role of vitamins that are abundant in fruit and vegetables has produced variable results with the risk of RCC with some reporting an association with RCC [41] whilst others have reported no correlation [42-44] whilst analysis of cohort studies has reported that diets rich in fruits and vegetables are inversely related to RCC [45]. High consumption of fat and protein has not been shown to be associated with an increased risk of RCC [46-48]. The consumption of 
alcohol has also been demonstrated to have a negative relationship with risk of RCC in a dose response manner [49] whilst in contrast no correlation was demonstrated with total fluid intake from any fluids or from individual types of fluids [50, 51] suggesting that it is not duration of contact with any potential carcinogens which prevents RCC risk with alcohol consumption.

Of all RCC $2-3 \%$ are familial $[52,53]$ with a 2 -fold increase in a first degree relative [54]. Of the various subtypes of RCC, each has a corresponding hereditary component caused by a distinct genetic alteration [55]. The most common familial syndrome for RCC is von HippelLindau (VHL) syndrome which can also cause patients to develop pheochromocytomas, retinal angiomas and hemangioblastomas of the central nervous system with only $40 \%$ suffering from RCC with VHL. The VHL gene is responsible for the degradation of hypoxia inducible factors without which leads to up-regulation of factors which promote angiogenesis and tumour growth such as vascular endothelial growth factor. In those with VHL syndrome, RCC is the most common cause of death.

Various medical conditions have been demonstrated to have an association with an increased risk of RCC. Types of renal tumors have been shown to cause hypertension [56]. Interestingly however, several studies have reported an association with long-term hypertension and risk of RCC [32, 33, 40, 57] as well as some reporting a dose response relationship [32] with the risk of RCC increasing with further elevation of blood pressure and decreasing with a reduction in blood pressure [57]. There have been reports that usage of anti-hypertensive treatment is also associated with an elevated risk of RCC but it is thought that it is hypertension causing this increased risk and not the actual treatment [32, 35, 36, 39, 58]. Obesity as a risk factor has already been mentioned but it has been reported that despite the relationship between obesity and hypertension, both are independent with their association with RCC and risk is higher in amongst those suffering from both conditions than those with only one [32, 36, 39, 57].

Diabetes mellitus is known to be associated with an increased risk of several cancers. Its relationship in RCC has not been demonstrated to be an independent factor but was closely associated with obesity and hypertension [35, 36, 40, 58-63].

It has been demonstrated that acquired renal cystic disease develops in those with end stage renal disease and in those on hemodialysis [64]. The incidence of RCC is higher in those with cystic disease [65, 66] but the evidence suggesting that these cysts undergo malignant

Epidemiology and Risk Factors for Renal Cancer change is not conclusive $[66,67]$. Those who are undergoing hemodialysis are at a higher risk of RCC [67-69] as well as there being an increased risk of RCC after renal transplantation [69-71].

There has some been controversy surrounding an association between urinary tract infections and RCC, one study suggests that a history of a urinary tract infection increases the risk of RCC and this risk is further exacerbated with a history of smoking [72] whilst another report has demonstrated that no relationship between these parameters is present [73].

\section{Conclusion}

The incidence and mortality rates of renal cancer are starting to stabilise. Despite increasing usage of imaging, many tumors present at advanced stages. The rise in hypertension and obesity which are well established factors for RCC are likely to have contributed to the upward trend in recent years. The impact of smoking on RCC will decrease in Western countries but may grow in developing countries. Despite the evidence of various genetic, iatrogenic and lifestyle risk factors associated with RCC further work is required from well designed epidemiological studies incorporating these various factors to gain further understanding of the etiology of renal cancer. 


\section{References}

$\checkmark 1$ Ferlay J, Shin HR, Bray F, Forman D, 17 Moore LE, Boffetta P, Karami S, Brennan P, Mathers C, Parkin DM: Estimates of worldwide burden of cancer in 2008: GLOBOCAN 2008. Int J Cancer 2010;127:2893-2917.

2 www.cancerresearchuk.org.

$>3$ Chow WH, Devesa SS, Warren JL, Fraumeni JF Jr: Rising incidence of renal cell cancer in the United States. JAMA 1999;281:16281631.

4 Hollingsworth JM, Miller DC, Daignault S, Hollenbeck BK: Rising incidence of small renal masses: a need to reassess treatment effect. J Natl Cancer Inst 2006;98:1331-1334.

-5 Jayson M, Sanders H: Increased incidence of serendipitously discovered renal cell carcinoma. Urology 1998;51:203-205.

6 Nguyen MM, Gill IS, Ellison LM: The evolving presentation of renal carcinoma in the United States: trends from the Surveillance, Epidemiology, and End Results program. J Urol 2006;176:2397-2400

7 Tate R, Iddenden R, Harnden P, Morris E, Craigs C, Bennett C, Brook C, Haward RA, Forman D: Increased incidence of renal parenchymal carcinoma in the Northern and Yorkshire region of England, 1978-1997. Eur J Cancer 2003;39:961-967.

>8 Gupta K, Miller JD, Li JZ, Russell MW, Charbonneau C: Epidemiologic and socioeconomic burden of metastatic renal cell carcinoma (mRCC): a literature review. Cancer Treat Rev 2008;34:193-205.

-9 Athar U, Gentile TC: Treatment options for metastatic renal cell carcinoma: a review. Can J Urol 2008;15:3954-3966.

10 Chow WH, Devesa SS: Contemporary epidemiology of renal cell cancer. Cancer J 2008; 14:288-301.

$\checkmark 11$ Mistry M, Parkin DM, Ahmad AS, Sasieni P: Cancer incidence in the United Kingdom: projections to the year 2030. Br J Cancer 2011;105:1795-1803.

$\checkmark 12$ Hunt JD, van der Hel OL, McMillan GP, Boffetta P, Brennan P: Renal cell carcinoma in relation to cigarette smoking: meta-analysis of 24 studies. Int J Cancer 2005;114:101108.

13 Parker AS, Cerhan JR, Janney CA, Lynch CF, Cantor KP: Smoking cessation and renal cell carcinoma. Ann Epidemiol 2003;13:245251.

14 Sharifi N, Farrar WL: Perturbations in hypoxia detection: a shared link between hereditary and sporadic tumor formation? Med Hypotheses 2006;66:732-735.

$\$ 15$ Clague J, Shao L, Lin J, Chang S, Zhu Y, Wang W, Wood CG, Wu X: Sensitivity to NNKOAc is associated with renal cancer risk. Carcinogenesis 2009;30:706-710.

$\checkmark 16$ Chiu WA, Caldwell JC, Keshava N, Scott CS: Key scientific issues in the health risk assessment of trichloroethylene. Environ Health Perspect 2006;114:1445-1449. Stewart PS, Hung R, Zaridze D, Matveev V, Janout V, Kollarova H, Bencko V, Navratilova M, Szeszenia-Dabrowska N, Mates D, Gromiec J, Holcatova I, Merino M, Chanock S, Chow WH, Rothman N: Occupational trichloroethylene exposure and renal carcinoma risk: evidence of genetic susceptibility by reductive metabolism gene variants. Cancer Res 2010;70:6527-6536.

18 Scott CS, Chiu WA: Trichloroethylene cancer epidemiology: a consideration of select issues. Environ Health Perspect 2006;114: 1471-1478.

19 Kelsh MA, Alexander DD, Mink PJ, Mandel JH: Occupational trichloroethylene exposure and kidney cancer: a meta-analysis. Epidemiology 2010;21:95-102.

20 Caldwell JC, Keshava N, Evans MV: Difficulty of mode of action determination for trichloroethylene: an example of complex interactions of metabolites and other chemical exposures. Environ Mol Mutagen 2008;49: 142-154.

21 Boffetta P, Fontana L, Stewart P, Zaridze D, Szeszenia-Dabrowska N, Janout V, Bencko V, Foretova L, Jinga V, Matveev V, Kollarova $\mathrm{H}$, Ferro G, Chow WH, Rothman N, van Bemmel D, Karami S, Brennan P, Moore LE: Occupational exposure to arsenic, cadmium, chromium, lead and nickel, and renal cell carcinoma: a case-control study from Central and Eastern Europe. Occup Environ Med 2011;68:723-728.

-22 Karami S, Boffetta P, Stewart PS, Brennan P, Zaridze D, Matveev V, Janout V, Kollarova H, Bencko V, Navratilova M, SzeszeniaDabrowska N, Mates D, Gromiec J, Slamova A, Chow WH, Rothman N, Moore LE: Occupational exposure to dusts and risk of renal cell carcinoma. Br J Cancer 2011;104:17971803.

23 Canu IG, Ellis ED, Tirmarche M: Cancer risk in nuclear workers occupationally exposed to uranium-emphasis on internal exposure. Health Phys 2008;94:1-17.

24 Il'yasova D, Schwartz GG: Cadmium and renal cancer. Toxicol Appl Pharmacol 2005; 207:179-186.

25 Heck JE, Charbotel B, Moore LE, Karami S, Zaridze DG, Matveev V, Janout V, Kollárová $\mathrm{H}$, Foretova L, Bencko V, SzeszeniaDabrowska N, Lissowska J, Mates D, Ferro G, Chow WH, Rothman N, Stewart P, Brennan P, Boffetta P: Occupation and renal cell cancer in Central and Eastern Europe. Occup Environ Med 2010;67:47-53.

26 Calle EE, Kaaks R: Overweight, obesity and cancer: epidemiological evidence and proposed mechanisms. Nat Rev Cancer 2004;4: 579-591.
27 Oh SW, Yoon YS, Shin SA: Effects of excess weight on cancer incidences depending on cancer sites and histologic findings among men: Korea National Health Insurance Corporation Study. J Clin Oncol 2005;23:47424754.

28 Pischon T, Lahmann PH, Boeing H, Tjonneland A, Halkjaer J, Overvad K, KlipsteinGrobusch K, Linseisen J, Becker N, Trichopoulou A, Benetou V, Trichopoulos D, Sieri S, Palli D, Tumino R, Vineis P, Panico S, Monninkhof E, Peeters PH, Bueno-de-Mesquita HB, Büchner FL, Ljungberg B, Hallmans G, Berglund G, Gonzalez CA, Dorronsoro $\mathrm{M}$, Gurrea $\mathrm{AB}$, Navarro $\mathrm{C}$, Martinez C, Quirós JR, Roddam A, Allen N, Bingham S, Khaw KT, Kaaks R, Norat T, Slimani N, Riboli E: Body size and risk of renal cell carcinoma in the European Prospective Investigation into Cancer and Nutrition (EPIC). Int J Cancer 2006;118:728-738

29 Reeves GK, Pirie K, Beral V, Green J, Spencer E, Bull D: Cancer incidence and mortality in relation to body mass index in the Million Women Study: cohort study. BMJ 2007;335: 1134.

-30 Adams KF, Leitzmann MF, Albanes D, Kipnis V, Moore SC, Schatzkin A, Chow WH: Body size and renal cell cancer incidence in a large US cohort study. Am J Epidemiol 2008; 168:268-277.

31 Renehan AG, Tyson M, Egger M, Heller RF, Zwahlen M: Body-mass index and incidence of cancer: a systematic review and metaanalysis of prospective observational studies. Lancet 2008;371:569-578.

32 Weikert S, Boeing H, Pischon T, Weikert C, Olsen A, Tjonneland A, Overvad K, Becker N, Linseisen J, Trichopoulou A, Mountokalakis T, Trichopoulos D, Sieri S, Palli D, Vineis P, Panico S, Peeters PH, Bueno-de-Mesquita HB, Verschuren WM, Ljungberg B, Hallmans G, Berglund G, González CA, Dorronsoro M, Barricarte A, Tormo MJ, Allen N, Roddam A, Bingham S, Khaw KT, Rinaldi S, Ferrari P, Norat T, Riboli E: Blood pressure and risk of renal cell carcinoma in the European prospective investigation into cancer and nutrition. Am J Epidemiol 2008;167:438-446.

33 Vatten LJ, Trichopoulos D, Holmen J, Nilsen TI: Blood pressure and renal cancer risk: the HUNT Study in Norway. Br J Cancer 2007; 97:112-114.

34 van Dijk BA, Schouten LJ, Kiemeney LA, Goldbohm RA, van den Brandt PA: Relation of height, body mass, energy intake, and physical activity to risk of renal cell carcinoma: results from the Netherlands Cohort Study. Am J Epidemiol 2004;160:1159-1167.

- 35 Setiawan VW, Stram DO, Nomura AM, Kolonel LN, Henderson BE: Risk factors for renal cell cancer: the multiethnic cohort. Am J Epidemiol 2007;166:932-940. 
-36 Nicodemus KK, Sweeney C, Folsom AR: Evaluation of dietary, medical and lifestyle risk factors for incident kidney cancer in postmenopausal women. Int J Cancer 2004;108: $115-121$.

-37 Moore SC, Chow WH, Schatzkin A, Adams KF, Park Y, Ballard-Barbash R, Hollenbeck A, Leitzmann MF: Physical activity during adulthood and adolescence in relation to renal cell cancer. Am J Epidemiol 2008;168:149157.

-38 Mahabir S, Leitzmann MF, Pietinen P, Albanes D, Virtamo J, Taylor PR: Physical activity and renal cell cancer risk in a cohort of male smokers. Int J Cancer 2004; 108:600_ 605.

-39 Flaherty KT, Fuchs CS, Colditz GA, Stampfer MJ, Speizer FE, Willett WC, Curhan DC: A prospective study of body mass index, hypertension, and smoking and the risk of renal cell carcinoma (United States). Cancer Causes Control 2005;16:1099-1106.

-40 Choi MY, Jee SH, Sull JW, Nam CM: The effect of hypertension on the risk for kidney cancer in Korean men. Kidney Int 2005;67: 647-652.

41 Lee JE, Giovannucci E, Smith-Warner SA, Spiegelman D, Willett WC, Curhan GC: Intakes of fruits, vegetables, vitamins $\mathrm{A}, \mathrm{C}$, and $\mathrm{E}$, and carotenoids and risk of renal cell cancer. Cancer Epidemiol Biomarkers Prev 2006;15:2445-2452.

-42 Weikert S, Boeing H, Pischon T, Olsen A, Tjonneland A, Overvad K, Becker N, Linseisen J, Lahmann PH, Arvaniti A, Kassapa C, Trichoupoulou A, Sieri S, Palli D, Tumino R, Vineis P, Panico S, van Gils CH, Peeters $\mathrm{PH}$, Bueno-de-Mesquita HB, Büchner FL, Ljungberg B, Hallmans G, Berglund G, Wirfält E, Pera G, Dorronsoro M, Gurrea AB, Navarro C, Martinez C, Quirós JR, Allen N, Roddam A, Bingham S, Jenab M, Slimani N, Norat T, Riboli E: Fruits and vegetables and renal cell carcinoma: findings from the European prospective investigation into cancer and nutrition (EPIC). Int $\mathbf{J}$ Cancer 2006;118:3133-3139.

-43 van Dijk BA, Schouten LJ, Oosterwijk E, Hulsbergen-Van de Kaa CA, Kiemeney LA, Goldbohm RA, Schalken JA, van den Brand PA: Carotenoid and vitamin intake, von Hippel-Lindau gene mutations and sporadic renal cell carcinoma. Cancer Causes Control 2008; 19:125-134.

-44 Bertoia M, Albanes D, Mayne ST, Mannisto S, Virtamo J, Wright ME: No association between fruit, vegetables, antioxidant nutrients and risk of renal cell carcinoma. Int $\mathrm{J}$ Cancer 2010;126:1504-1512.
45 Lee JE, Mannisto S, Spiegelman D, Hunter DJ, Bernstein L, van den Brandt PA, Buring JE, Cho E, English DR, Flood A, Freudenheim JL, Giles GG, Giovannucci E, Håkansson N, Horn-Ross PL, Jacobs EJ, Leitzmann MF, Marshall JR, McCullough ML, Miller AB, Rohan TE, Ross JA, Schatzkin A, Schouten LJ, Virtamo J, Wolk A, Zhang SM, Smith-Warner SA: Intakes of fruit, vegetables, and carotenoids and renal cell cancer risk: a pooled analysis of 13 prospective studies. Cancer Epidemiol Biomarkers Prev 2009;18:1730-1739.

46 Lee JE, Spiegelman D, Hunter DJ, Albanes $\mathrm{D}$, Bernstein L, van den Brandt PA, Buring JE, Cho E, English DR, Freudenheim JL, Giles GG, Graham S, Horn-Ross PL, Håkansson N, Leitzmann MF, Männistö S, McCullough ML, Miller AB, Parker AS, Rohan TE, Schatzkin A, Schouten LJ, Sweeney C, Willett WC, Wolk A, Zhang SM, SmithWarner SA: Fat, protein, and meat consumption and renal cell cancer risk: a pooled analysis of 13 prospective studies. J Natl Cancer Inst 2008;100:1695-1706.

47 Allen NE, Roddam AW, Sieri S, Boeing H, Jakobsen MU, Overvad K, Tjonneland A, Halkjaer J, Vineis P, Contiero P, Palli D, Tumino R, Mattiello A, Kaaks R, Rohrmann S, Trichopoulou A, Zilis D, Koumantaki Y, Peeters PH, Bueno-de-Mesquita HB, Barricarte A, Rodríguez L, Dorronsoro M, Sánchez MJ, Chirlaque MD, Esquius L, Manjer J, Wallström P, Ljungberg B, Hallmans G, Bingham S, Khaw KT, Boffetta P, Norat T, Mouw T, Riboli E: A prospective analysis of the association between macronutrient intake and renal cell carcinoma in the European Prospective Investigation into Cancer and Nutrition. Int J Cancer 2009;125:982-987.

48 Alexander DD, Cushing CA: Quantitative assessment of red meat or processed meat consumption and kidney cancer. Cancer Detect Prev 2009;32:340-351.

49 Lee JE, Hunter DJ, Spiegelman D, Adami HO, Albanes D, Bernstein L, van den Brandt PA, Buring JE, Cho E, Folsom AR, Freudenheim JL, Giovannucci E, Graham S, HornRoss PL, Leitzmann MF, McCullough ML, Miller AB, Parker AS, Rodriguez C, Rohan TE, Schatzkin A, Schouten LJ, Virtanen M, Willett WC, Wolk A, Zhang SM, Smith-Warner SA: Alcohol intake and renal cell cancer in a pooled analysis of 12 prospective studies. J Natl Cancer Inst 2007:99:801-810.

50 Lee JE, Hunter DJ, Spiegelman D, Adami HO, Bernstein L, van den Brandt PA, Buring JE, Cho E, English D, Folsom AR, Freudenheim JL, Gile GG, Giovannucci E, Horn-Ross PL, Leitzmann M, Marshall JR, Männistö S, McCullough ML, Miller AB, Parker AS, Pietinen P, Rodriguez C, Rohan TE, Schatzkin A, Schouten LJ, Willett WC, Wolk A, Zhang SM, Smith-Warner SA: Intakes of coffee, tea, milk, soda and juice and renal cell cancer in a pooled analysis of 13 prospective studies. Int J Cancer 2007;121:2246-2253.
-51 Lee JE, Giovannucci E, Smith-Warner SA, Spiegelman D, Willett WC, Curhan GC: Total fluid intake and use of individual beverages and risk of renal cell cancer in two large cohorts. Cancer Epidemiol Biomarkers Prev 2006; 15:1204-1211.

52 Lipworth L, Tarone RE, McLaughlin JK: The epidemiology of renal cell carcinoma. J Urol 2006; 176:2353-2358.

53 Coleman JA: Familial and hereditary renal cancer syndromes. Urol Clin North Am 2008;35:563-572.

-54 Clague J, Lin J, Cassidy A, Matin S, Tannir NM, Tamboli P, Wood CG, Wu X: Family history and risk of renal cell carcinoma: results from a case-control study and systematic meta-analysis. Cancer Epidemiol Biomarkers Prev 2009;18:801-807.

55 Cohen D, Zhou M: Molecular genetics of familial renal cell carcinoma syndromes. Clin Lab Med 2005;25:259-277.

56 Steffens J, Bock R, Braedel HU, Isenberg E, Buhrle CP, Ziegler M: Renin-producing renal cell carcinomas--clinical and experimental investigations on a special form of renal hypertension. Urol Res 1992;20:111-115.

57 Chow WH, Gridley G, Fraumeni JF Jr, Jarvholm B: Obesity, hypertension, and the risk of kidney cancer in men. N Engl J Med 2000;343:1305-1311.

-58 Schouten LJ, van Dijk BA, Oosterwijk E, Hulsbergen-Van de Kaa CA, Kiemeney LA, Goldbohm RA, Schalken JA, van den Brandt PA: Hypertension, antihypertensives and mutations in the Von Hippel-Lindau gene in renal cell carcinoma: results from the Netherlands Cohort Study. J Hypertens 2005;23: 1997-2004.

59 Gago-Dominguez M, Castelao JE, Yuan JM, Ross RK, Yu MC: Lipid peroxidation: a novel and unifying concept of the etiology of renal cell carcinoma (United States). Cancer Causes Control 2002;13:287-293.

60 Inoue M, Iwasaki M, Otani T, Sasazuki S, Noda M, Tsugane S: Diabetes mellitus and the risk of cancer: results from a large-scale population-based cohort study in Japan. Arch Intern Med 2006;166:1871-1877.

61 Kearney PM, Whelton M, Reynolds K, Muntner P, Whelton PK, He J: Global burden of hypertension: analysis of worldwide data. Lancet 2005;365:217-223

62 Mittal BV, Singh AK: Hypertension in the developing world: challenges and opportunities. Am J Kidney Dis 2010;55:590-598.

63 Lindblad P, Chow WH, Chan J, Bergstrom A, Wolk A, Gridley G, McLaughlin JK, Nyrén O, Adami HO: The role of diabetes mellitus in the aetiology of renal cell cancer. Diabetologia 1999;42:107-112.

64 Miller LR, Soffer O, Nassar VH, Kutner MH: Acquired renal cystic disease in end-stage renal disease: an autopsy study of 155 cases. Am J Nephrol 1989;9:322-328. 
65 Port FK, Ragheb NE, Schwartz AG, Hawthorne VM: Neoplasms in dialysis patients: a population-based study. Am J Kidney Dis 1989;14:119-123.

66 Bonsib SM: Renal cystic diseases and renal neoplasms: a mini-review. Clin J Am Soc Nephrol 2009;4:1998-2007.

-67 Denton MD, Magee CC, Ovuworie C, Mauiyyedi S, Pascual M, Colvin RB, Cosimi AB, Tolkoff-Rubin N: Prevalence of renal cell carcinoma in patients with ESRD pre-transplantation: a pathologic analysis. Kidney Int 2002;61:2201-2209.

-68 Nouh MA, Kuroda N, Yamashita M, Hayashida Y, Yano T, Minakuchi J, Taniguchi S, Nomura I, Inui M, Sugimoto M, Kakehi Y: Renal cell carcinoma in patients with endstage renal disease: relationship between histological type and duration of dialysis. BJU Int 2010;105:620-627.
69 Stewart JH, Vajdic CM, van Leeuwen MT, Amin J, Webster AC, Chapman JR, McDonald SP, Grulich AE, McCredie MR: The pattern of excess cancer in dialysis and transplantation. Nephrol Dial Transplant 2009;24: 3225-3231.

70 Vajdic CM, McDonald SP, McCredie MR, van Leeuwen MT, Stewart JH, Law M, Chapman JR, Webster AC, Kaldor JM, Grulich AE: Cancer incidence before and after kidney transplantation. JAMA 2006;296:28232831.
71 Klatte T, Seitz C, Waldert M, de MM, Kikic Z, Bohmig GA, Haitel A, Schmidbauer J, Marberger M, Remzi M: Features and outcomes of renal cell carcinoma of native kidneys in renal transplant recipients. BJU Int 2010;105:1260-1265.

72 Parker AS, Cerhan JR, Lynch CF, Leibovich BC, Cantor KP: History of urinary tract infection and risk of renal cell carcinoma. Am J Epidemiol 2004;159:42-48.

73 Chow WH, Lindblad P, Gridley G, Nyren O, McLaughlin JK, Linet MS, Pennello GA, Adami HO, Fraumeni JF Jr: Risk of urinary tract cancers following kidney or ureter stones. J Natl Cancer Inst 1997;89:1453-1457. 